\title{
Disparitas Harga Pangan Strategis Sebelum dan Saat Pandemi COVID-19
}

\author{
Muhammad Firdaus ${ }^{\mathrm{a}, *}$ \\ ${ }^{a}$ Departemen Ilmu Ekonomi, Fakultas Ekonomi dan Manajemen, IPB University
}

\begin{abstract}
This study aims to compare the variability and convergence of strategic food prices before and during the COVID-19 pandemic in Indonesia. The weekly prices data of 9 food commodities in 34 provinces during 2019 and 2020 was used. The price variability and convergence are analyzed using the coefficient of variation and dynamic data panel, respectively. The result showed that the rice, beef, red chilies, chicken meat, and chicken eggs experienced a decrease in price variability while sugar, shallots, garlic, and cayenne pepper exhibited the opposite. Prices movement among regions tends to show increasing price variability, with the exception of chicken eggs. Some efforts such as supply management through structuring production over time, efficiency of distribution between regions is imperative to stabilize food prices. Besides, efforts such as a market contract system, warehouse receipt systems and strengthening Local Government-Owned Enterprise for food supply management are crucial.
\end{abstract}

Keywords: horticulture; convergence; dynamic panel data; variability

\begin{abstract}
Abstrak
Penelitian ini bertujuan untuk membandingkan variabilitas dan konvergensi harga pangan strategis sebelum dan selama pandemi COVID-19 di Indonesia. Data yang digunakan adalah harga mingguan 9 komoditas pangan di 34 provinsi selama 2019 dan 2020. Variabilitas dan konvergensi harga dianalisis menggunakan koefisien variasi dan data panel dinamis. Hasil penelitian menunjukkan bahwa beras, daging sapi, cabai merah, daging ayam, dan telur ayam mengalami penurunan variabilitas harga, sedangkan gula, bawang merah, bawang putih, dan cabai rawit mengalami sebaliknya. Pergerakan harga antarwilayah menunjukkan variabilitas harga yang cenderung meningkat, kecuali harga telur ayam. Beberapa hal yang dapat dilakukan untuk menstabilkan harga pangan adalah manajemen pasokan melalui penataan produksi antarwaktu dan efisiensi distribusi antardaerah. Selain itu, sistem kontrak pemasaran, sistem resi gudang, dan penguatan Badan Usaha Milik Daerah untuk pengelolaan pasokan makanan sangatlah penting.
\end{abstract}

Kata Kunci: hortikultura; konvergensi harga; data panel dinamis; variabilitas harga Kode Klasifikasi JEL: E31; Q11; Q18

\footnotetext{
${ }^{*}$ Alamat Korespondensi Penulis: Gedung FEM Lantai 2, Jl. Agatis, IPB Dramaga Campus, Bogor West Java - Indonesia 16680, Phone/Fax: +62 251-8626602. E-mail: firdausfemipb@yahoo.com.
} 


\section{Pendahuluan}

Pangan strategis adalah komoditas pangan yang memiliki pengaruh yang sangat kuat dalam pembentukan angka inflasi (strategis), terutama terkait angka inflasi yang dipengaruhi oleh gejolak harga dalam kelompok barang seperti bahan makanan atau volatile food. Pemerintah Indonesia telah mengeluarkan dua Undang-undang terkait ketahanan dan stabilitas harga pangan, yaitu Undangundang Nomor 18 Tahun 2012 tentang Pangan dan Undang-undang Nomor 7 Tahun 2014 tentang Perdagangan (FAO, 2010). Stabilitas harga pangan sangat dijaga karena pangan mempunyai pengaruh politis yang tinggi. Fluktuasi yang terlalu tinggi dari harga komoditas pangan dapat memberikan dampak yang sangat merugikan bagi petani, pengolah, pedagang, hingga konsumen dan berpotensi menimbulkan keresahan sosial (Sari, 2010). Melalui komponen volatile food, harga pangan memengaruhi tingkat inflasi Indonesia dan secara historis, sumbangan kelompok volatile food terhadap inflasi Indonesia sangat signifikan. Kenaikan harga pangan dipengaruhi secara signifikan oleh pasokan yang tidak terkendali (Serra \& Gill, 2013). Keterbatasan pasokan dapat dipengaruhi oleh perubahan iklim, bencana alam, krisis ekonomi, dan guncangan luar lainnya, seperti pandemi COVID-19. Namun, peningkatan produksi pertanian memerlukan proses yang tidak instan karena terkait dengan infrastruktur, luas lahan, teknologi, dan keahlian yang memerlukan investasi dan penanganan jangka panjang (Prastowo et al., 2008).

Keterkaitan dampak pandemi COVID-19 terhadap fluktuasi harga pangan menjadi perhatian serius. FAO (2020) memberikan peringatan yang sangat penting terkait upaya mitigasi setiap negara dalam menghadapi dampak dari COVID19 yang tentunya pasokan pangan akan terganggu. Dengan penyediaan pangan melalui rantai pasok global, diperkirakan dapat memengaruhi situasi di beberapa negara, termasuk Indonesia. Menurut FAO, dari April hingga Mei 2020 adalah saat ketika dampak ini akan sangat terasa.

Berdasarkan data Pusat Informasi Harga Pangan Strategis Nasional (PIHPS), perbandingan data pergerakan harga pangan mingguan tahun 2019 dan 2020, pada beberapa komoditas menunjukkan perbedaan pola pergerakan. Harga bawang putih pada tahun 2019 mencapai harga tertinggi pada Mei dengan harga sebesar Rp61.500, setelah itu secara bertahap mengalami penurunan hingga akhir tahun. Sedangkan pada tahun 2020, harga bawang putih mencapai harga tertinggi pada Februari dengan harga sebesar Rp55.200, setelah itu harga secara bertahap mengalami penurunan. Harga bawang putih sangat dipengaruhi oleh pasokan dari Tiongkok. Harga bawang putih meningkat lebih cepat karena dampak COVID-19 di Tiongkok yang lebih awal. Hal yang sama juga terjadi pada komoditas cabe merah dan cabe rawit, harga meningkat signifikan pada Januari hingga Februari 2020. Berbeda dari tahun 2019, di mana harga cabe rawit dan cabe merah cenderung turun pada Januari hingga Februari.

Kemudian, fluktuasi harga bawang merah terlihat sangat berbeda antara tahun 2019 dan 2020. Pada tahun 2019, harga bawang merah berfluktuasi di 

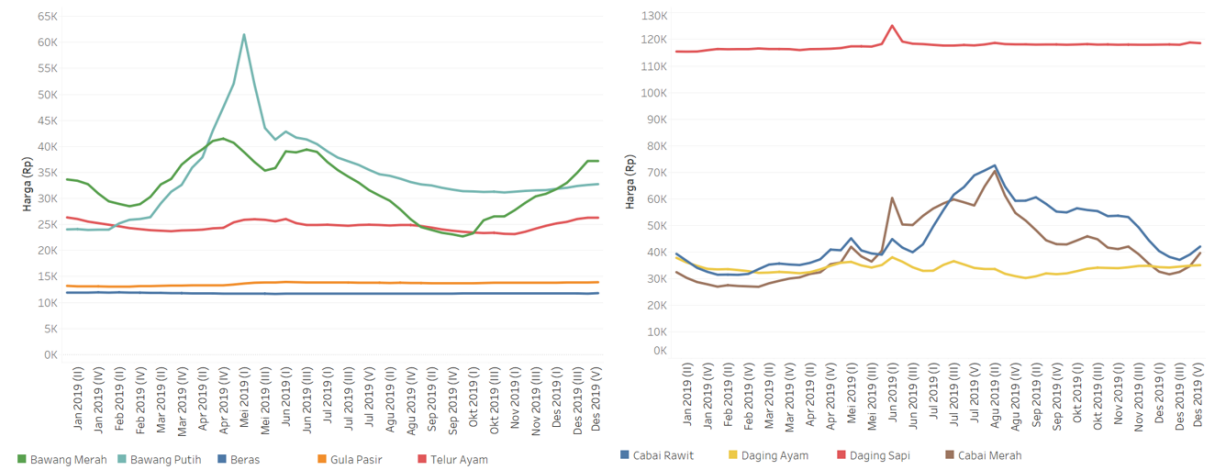

(a) Pergerakan harga pangan strategis tahun 2019
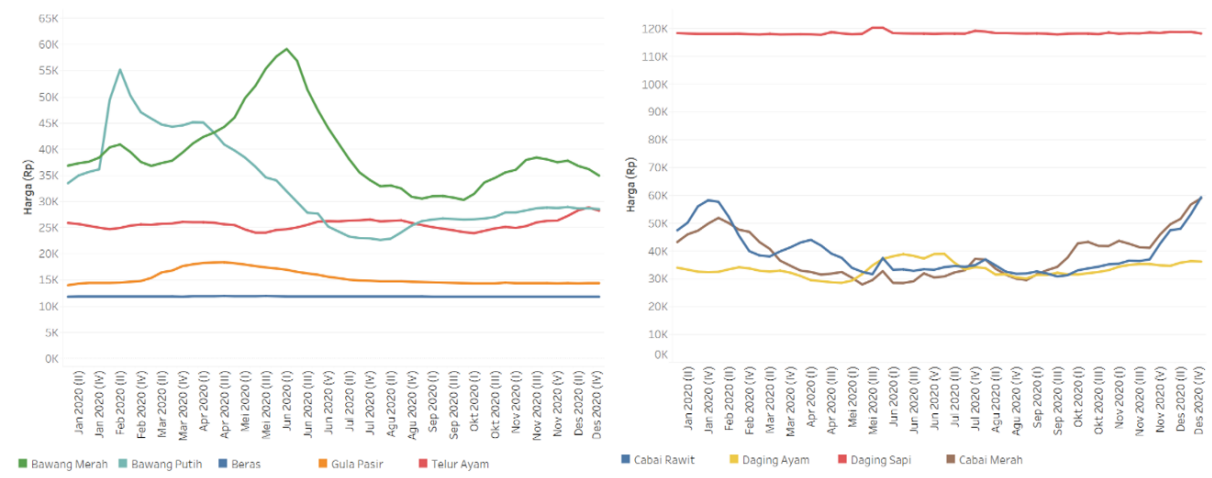

(b) Pergerakan harga pangan strategis tahun 2020

\section{Gambar 1: Pergerakan Harga Pangan Strategis Tahun 2019 dan 2020}

Sumber: PIHPS (2021)

antara harga Rp20.000-Rp40.000. Sedangkan pada tahun 2020, harga bawang merah berfluktuasi di antara harga Rp30.000-Rp60.000, dengan harga tertinggi mencapai Rp59.150 pada awal Juni 2020. Selanjutnya, harga gula pasir yang cenderung stabil pada tahun 2019, terlihat mengalami kenaikan signifikan pada Maret-Mei 2020. Sementara itu, harga beras, daging ayam, daging sapi dan telur ayam cenderung stabil, baik pada tahun 2019 maupun tahun 2020.

Pandemi COVID-19 menyebabkan pasokan pangan tertentu terganggu karena dibatasinya berbagai aktivitas produksi dan distribusi. Keterbatasan tersebut memicu inflasi Indonesia yang terus meningkat selama Pandemi COVID-19 melalui fluktuasi harga pangan strategis. Bank Indonesia (2020) mencatat inflasi 0,28 persen $(\mathrm{mtm})$ berdasarkan data pada November 2020, Indeks Harga Konsumen (IHK) lebih tinggi dari Oktober yang inflasinya tercatat sebesar 0,07 persen dan 
lebih tinggi dari tahun sebelumnya sebesar 0,14 persen. Hal tersebut dipengaruhi kelompok volatile food dan kelompok administered price di tengah inflasi inti yang tetap rendah. Inflasi pada kelompok volatile food tercatat sebesar 1,31 persen ( $\mathrm{mtm}$ ) pada November 2020, lebih tinggi dari Oktober sebesar 0,40 persen (mtm). Angka inflasi yang meningkat tersebut disebabkan akibat kenaikan harga daging ayam ras, telur ayam ras, minyak goreng, dan komoditas hortikultura yang terdampak pandemi.

Inflasi yang fluktuatif dapat mengakibatkan ketidakpastian bagi pelaku ekonomi dalam mempertimbangkan pengambilan keputusan sebelum melakukan konsumsi, investasi, dan produksi yang berujung pada penurunan pertumbuhan ekonomi. Daya beli masyarakat dapat diproksikan melalui inflasi inti. Badan Pusat Statistik (2020) mencatat inflasi inti pada Oktober 2020 sebesar 0,04 persen (mtm), lebih rendah dibandingkan dengan Oktober, yaitu 0,13 persen dan Agustus 0,29 persen yang menandakan daya beli masyarakat belum pulih bahkan menurun karena pandemi COVID-19. Gejolak harga pangan salah satunya disebabkan oleh perubahan daya beli masyarakat, khususnya pada kelompok berpenghasilan rendah. Bank Indonesia menyatakan bahwa lemahnya daya beli disebabkan permintaan yang belum kuat karena pendapatan masyarakat yang terganggu disebabkan banyaknya pembatasan aktivitas oleh pemerintah selama pandemi COVID-19.

Struktur pasar komoditas pertanian pada umumnya bersifat persaingan tidak sempurna atau imperfect competition dapat memicu pembentukan harga yang asimetris (Miller \& Hayenga, 2001; Meyer \& von Cramon-Taubadel, 2004). Kementerian Pertanian menyebutkan asimetri harga terjadi jika kenaikan harga di tingkat konsumen sangat responsif terhadap kenaikan harga pada tingkat produsen, namun sering kali kurang responsif ketika terjadi penurunan harga pada tingkat produsen (Magfiroh et al., 2017). Hal tersebut juga sesuai dengan penelitian Gilbert \& Morgan (2010) bahwa harga pangan memengaruhi harga konsumen yang ditentukan oleh produsen. Oleh karena itu, perlu ada informasi harga dan pasokan pangan agar dapat mendorong pembentukan harga yang lebih adil bagi seluruh pelaku distribusi. Peran berbagai pihak seperti Badan Ketahanan Pangan Kementerian Pertanian (2019), BULOG, Satgas Pangan, dan Kementerian Perdagangan (2015) sangat diperlukan. Selain dengan swadaya sosial, pemerintah juga harus mengatur harga pangan agar pergerakannya tidak terlalu fluktuatif.

Berdasarkan uraian di atas, terdapat urgensi kajian mengenai variabilitas dan disparitas harga pangan antarwaktu dan antarwilayah sebelum dan saat COVID-19. Hal ini karena terdapat perbedaan pola pergerakan dari biasanya. Oleh sebab itu, tujuan dari penelitian ini adalah (i) membandingkan variabilitas harga pangan strategis antarwaktu pada sebelum dan saat COVID-19, (ii) membandingkan variabilitas harga pangan strategis antarwilayah di Indonesia pada sebelum dan saat COVID-19, dan (iii) menganalisis konvergensi harga pangan strategis di Indonesia sebelum dan selama masa pandemi COVID-19. 


\section{Metodologi}

Data yang digunakan dalam penelitian ini adalah data sekunder harga komoditas pangan strategis 34 provinsi tahun 2019 sampai 2020 dengan periode waktu mingguan. Komoditas pangan yang menjadi bahan penelitian adalah beras, cabe merah, cabe rawit, gula pasir, bawang putih, bawang merah, daging sapi, daging ayam, dan telur ayam. Periode waktu yang dipilih bertujuan untuk membandingkan variabilitas dan konvergensi harga pangan strategis sebelum dan saat pandemi COVID-19 untuk setiap komoditas dan provinsi di Indonesia. Data dalam penelitian diunduh dari Pusat Informasi Harga Pangan Strategis Nasional (PIHPS) yang dapat diunduh pada laman hargapangan.id.

Berbagai penelitian tentang fluktuasi harga pangan telah dilakukan di Indonesia di antaranya oleh Kariyasa \& Sinaga (2004) tentang faktor-faktor yang berpengaruh terhadap harga jagung, Firdaus \& Gunawan (2012) tentang integrasi pasar sayuran di Indonesia, serta Ramadhani \& Sumanjaya (2014) tentang fluktuasi harga kedelai. Sementara itu, pada penelitian ini, indikator yang digunakan untuk mengukur volatilitas atau fluktuasi harga kebutuhan pangan strategis adalah koefisien variasi (coefficient of variation) atau disebut variabilitas. Penelitian ini mengukur variabilitas harga pangan strategis antarwaktu dan antarwilayah di Indonesia sebelum dan saat pandemi COVID-19. Formula koefisien keragaman adalah:

$$
C V=\frac{s_{b}}{\bar{x}}
$$

dengan $C V$ adalah Koefisien variasi, $s_{b}$ adalah Simpangan baku harga pangan (rupiah), dan $\bar{x}$ adalah Harga pangan rata-rata (rupiah).

Metode dalam menganalisis konvergensi harga pangan antarwilayah di Indonesia menggunakan data panel dinamis First-Differences GMM (FD-GMM) dan System GMM. Lalu spesifikasi model konvergensi dari harga pangan akan menggunakan variabel dependen harga pangan untuk melihat konvergensi sebelum pandemi COVID-19 pada tahun 2019 dan selama pandemi COVID-19 pada tahun 2020. Menurut Barro et al. (1991), dengan adanya harga yang konvergen atau disparitas harga makin mengecil, berarti kebijakan pemerintah telah berhasil. Harga pangan yang menjadi fokus penelitian adalah tanaman hortikultura karena tingkat volatilitas tinggi dan model yang dihasilkan lebih robust. Tanaman hortikultura tersebut, yaitu bawang merah, bawang putih, cabe merah, dan cabe rawit. Berikut spesifikasi model pada penelitian ini.

$$
P_{i t}=\beta 1 P_{t-1}+\beta 2 \text { Pberas }_{i t}+\varepsilon_{i t}
$$

dengan $P_{i t}$ adalah Harga tingkat konsumen empat pangan hortikultura, yaitu bawang merah, bawang putih, cabe merah dan cabe rawit (rupiah); $P_{i t-1}$ adalah Harga tingkat konsumen periode sebelumnya (rupiah); Pberas ${ }_{i t}$ adalah Harga beras tingkat konsumen (rupiah); $\beta 1$ adalah Koefisien konvergensi; $\beta 2$ adalah Koefisien variabel harga beras; dan $\varepsilon_{\text {it }}$ adalah Error Term.

Apabila koefisien dari $\beta 1$ kurang dari satu, maka terjadi proses konvergensi 
dengan tingkat konvergensi dinyatakan sebagai $\lambda=(\gamma)$. Kemudian lag variabel dependen $P_{i t-1}$ pada sisi bagian kanan menunjukkan bahwa model yang digunakan adalah model dinamis. Pengolahan data dilakukan dengan menggunakan software Stata 15. Stata 15 menyediakan fitur analisis data panel dinamis secara lengkap.

\section{Hasil dan Pembahasan}

\subsection{Variabilitas Harga Pangan Antarwaktu Sebelum dan Saat Pandemi COVID-19}

Fluktuasi harga pangan pada saat pandemi COVID-19 mempunyai pengaruh besar terhadap stabilitas perekonomian negara. Beberapa harga pangan terlihat mengalami peningkatan pada saat sebelum dan saat pandemi COVID-19, namun juga terdapat harga pangan yang stabil. Besarnya fluktuasi harga pangan dapat digambarkan dengan nilai koefisien variasi (coefficient of variation). Tabel 1 menunjukkan nilai koefisien variasi antarwaktu untuk sembilan komoditas yang termasuk pangan strategis pada tahun 2019 dan 2020 di pasar tradisional dan modern.

Tabel 1: Nilai Koefisien Variasi Harga Pangan Antarwaktu Tahun 2019 dan 2020

\begin{tabular}{lcccc}
\hline \hline \multirow{2}{*}{ Komoditas } & \multicolumn{2}{c}{2019} & \multicolumn{2}{c}{2020} \\
\cline { 2 - 5 } & $\begin{array}{c}\text { CV Pasar } \\
\text { Tradisional }\end{array}$ & $\begin{array}{c}\text { CV Pasar } \\
\text { Modern }\end{array}$ & $\begin{array}{c}\text { CV Pasar } \\
\text { Tradisional }\end{array}$ & $\begin{array}{c}\text { CV Pasar } \\
\text { Modern }\end{array}$ \\
\hline Beras & 0,0065 & 0,0129 & 0,0033 & 0,0101 \\
Daging Ayam & 0,0489 & 0,0413 & 0,079 & 0,0309 \\
Daging Sapi & 0,0121 & 0,0078 & 0,0041 & 0,006 \\
Telur Ayam & 0,0357 & 0,0267 & 0,0395 & 0,0259 \\
Bawang Merah & 0,1625 & 0,0995 & 0,1838 & 0,1468 \\
Bawang Putih & 0,2202 & 0,1448 & 0,2587 & 0,2318 \\
Cabe Merah & 0,2795 & 0,1684 & 0,2085 & 0,1543 \\
Cabe Rawit & 0,2469 & 0,1472 & 0,1985 & 0,1506 \\
Gula Pasir & 0,0217 & 0,0099 & 0,0895 & 0,0425 \\
\hline Sumber: Data diolah dari PIHPS (2021) & &
\end{tabular}

Kondisi fluktuasi harga beras di tingkat konsumen saat pandemi mengalami penurunan dibandingkan sebelum pandemi, baik di pasar tradisional maupun pasar modern. Fluktuasi tersebut masih dapat dikatakan stabil dengan perubahan nilai koefisien variasi (CV) di pasar tradisional sebesar 0,003 dan pasar modern sebesar 0,002, masih di bawah 0,1. Hal yang sama juga terjadi pada komoditas daging sapi dan cabe merah, di mana nilai CV mengalami penurunan dalam batasan wajar. Nilai CV untuk daging sapi di pasar tradisional berubah sebesar 0,008 dan di pasar modern berubah sebesar 0,002. Sedangkan nilai CV untuk cabe merah di pasar tradisional berubah sebesar 0,07 dan di pasar modern berubah sebesar 0,01 . 
Sementara itu, harga gula pasir mengalami fluktuasi yang cukup signifikan selama tahun 2019 dan 2020. Nilai CV gula pasir mengalami peningkatan sebesar 0,07 di pasar tradisional dan sebesar 0,03 di pasar modern. Seperti halnya gula pasir, komoditas bawang merah dan bawang putih juga mengalami peningkatan fluktuasi baik di pasar tradisional maupun di pasar modern, dengan perubahan nilai CV sebesar 0,02-0,09. Komoditas lainnya, seperti daging ayam dan telur ayam, hanya mengalami peningkatan fluktuasi di pasar tradisional, sedangkan cabe rawit mengalami peningkatan fluktuasi hanya di pasar modern. Dari tabel tersebut terlihat bahwa komoditas hortikultura sebagian besar mengalami peningkatan fluktuasi harga akibat pandemi COVID-19.

Fluktuasi harga pangan pada saat pandemi COVID-19 mempunyai pengaruh besar terhadap stabilitas perekonomian negara. Beberapa harga pangan terlihat mengalami peningkatan pada masa sebelum dan selama pandemi COVID-19, namun juga terdapat harga pangan yang stabil. Secara keseluruhan, berdasarkan nilai koefisien variasi antarwaktu untuk sembilan komoditas yang termasuk pangan strategis pada tahun 2019 dan 2020 di pasar tradisional dan modern, masih dapat dikatakan stabil karena nilai perubahan CV di bawah 0,1. Artinya, tidak terdapat volatilitas harga yang terlalu tinggi.

\subsection{Variabilitas Harga Pangan Antarwilayah di Indonesia Sebelum dan Saat Pandemi COVID-19}

Nilai CV pada Tabel 2 mencerminkan keragaman harga komoditas pangan strategis pada setiap daerah ibukota provinsi di Indonesia. Pada tahun 2019-2020 nilai CV tertinggi ditempati oleh komoditas cabe rawit, artinya pada tahun 2019-2020, harga cabai rawit di setiap provinsi di Indonesia sangat beragam baik di pasar tradisional maupun pasar modern. Tingginya nilai CV komoditas cabe rawit mencerminkan ketidakstabilan harga cabe rawit antarprovinsi dan ketersediaannya. Nilai CV tertinggi antarprovinsi di Indonesia tahun 2019-2020 selalu ditempati oleh produk hortikultura dan kemudian diikuti oleh komoditas pangan strategis lainnya di pasar modern maupun pasar tradisional. Koefisien variasi komoditas pangan strategis tahun 2020 di pasar tradisional mengalami kenaikan dari tahun sebelumnya kecuali komoditas telur ayam dan bawang merah. Sedangkan di pasar modern komoditas beras, bawang putih, daging ayam, telur ayam, dan bawang merah nilai CV menurun dari tahun 2019.

Perubahan nilai $C V$ produk hortikultura setiap provinsi seperti cabe rawit dan cabe merah di pasar tradisional mengalami peningkatan sebesar 0,07 dan 0,04 namun di pasar modern komoditi cabe rawit mengalami peningkatan sebesar 0,08 dan cabe merah sebesar 0,07. Peningkatan nilai CV menandakan tingginya fluktuasi harga kedua komoditas tersebut selama 2019-2020. Fluktuasi harga pangan di pasar tradisional selain cabe rawit dan cabe merah berdasarkan nilai CV dapat dianggap masih berada pada batas wajar. Di pasar modern komoditas bawang putih, bawang merah, telur ayam, dan daging ayam mengalami penurunan nilai CV yang mencerminkan tingkat harga komoditas tersebut di 
Tabel 2: Nilai Koefisien Variasi Harga Pangan Antarwilayah Tahun 2019 dan 2020

\begin{tabular}{lcccc}
\hline \hline \multirow{2}{*}{ Komoditas } & \multicolumn{2}{c}{2019} & \multicolumn{2}{c}{2020} \\
\cline { 2 - 5 } & $\begin{array}{c}\text { CV Pasar } \\
\text { Tradisional }\end{array}$ & $\begin{array}{c}\text { CV Pasar } \\
\text { Modern }\end{array}$ & $\begin{array}{c}\text { CV Pasar } \\
\text { Tradisional }\end{array}$ & $\begin{array}{c}\text { CV Pasar } \\
\text { Modern }\end{array}$ \\
\hline Beras & 0,092385 & 0,152918 & 0,094301 & 0,146029 \\
Daging Ayam & 0,121405 & 0,166131 & 0,121556 & 0,138419 \\
Daging Sapi & 0,055721 & 0,167337 & 0,054040 & 0,168624 \\
Telur Ayam & 0,149621 & 0,187401 & 0,147614 & 0,169866 \\
Bawang Merah & 0,173639 & 0,174883 & 0,174047 & 0,171855 \\
Bawang Putih & 0,139576 & 0,229986 & 0,169115 & 0,175347 \\
Cabe Merah & 0,204484 & 0,168797 & 0,241418 & 0,238310 \\
Cabe Rawit & 0,236513 & 0,220069 & 0,316980 & 0,305931 \\
Gula Pasir & 0,068357 & 0,094465 & 0,077879 & 0,108157 \\
\hline Sumber: Hasil perhitungan penulis & &
\end{tabular}

setiap daerah menuju kestabilan dan harganya tidak terlalu berfluktuatif jika dibandingkan dengan tahun sebelumnya.

Berdasarkan perubahan nilai CV komoditas dari setiap wilayah menandakan bahwa pangan strategis sangat terdampak karena pandemi COVID-19. Meskipun fluktuasi atau perubahan harga masih stabil dan wajar, tetap perlu adanya intervensi pemerintah dalam pengendalian harga dan stok selama pandemik COVID-19. Hal ini karena terdapat beberapa komoditas yang mengalami perubahan CV di atas 0,05. Angka tersebut cukup rentan meningkat terus sehingga perlu kehati-hatian atau kebijakan yang dapat mencegah terjadinya perubahan harga yang lebih tinggi.

\subsection{Konvergensi Harga Pangan Sebelum dan Saat Pandemi COVID-19 di Indonesia}

Pada variabel dependennya, estimasi konvergensi harga pangan pokok dilakukan dengan menggunakan komoditas hortikultura, yaitu bawang merah, bawang putih, cabe rawit, dan cabe merah. Komoditas hortikultura dipilih karena mengalami fluktuasi harga yang cukup signifikan. Sehingga melalui perbandingan ini dapat terlihat apakah ada perbedaan konvergensi harga pangan pada empat komoditas tersebut antarwilayah di Indonesia pada masa sebelum dan selama pandemi COVID-19. Proses konvergensi harga pangan dapat terlihat dari koefisien parameter autoregressive dari variabel dependen. Nilai koefisien dari $P_{i t-1}$ yang kurang dari satu mengindikasikan adanya proses konvergensi atau disparitas harga akan semakin mengecil, sedangkan nilai koefisien yang lebih dari satu mengindikasikan bahwa harga pangan antarwilayah divergen.

Tabel 3 menunjukkan hasil estimasi konvergensi harga pangan tahun 2019 dengan metode data panel dinamis. Pada komoditi bawang merah nilai $P_{i t-1}$, yaitu sebesar 1,275 lebih besar dari satu sehingga tidak terjadi proses konvergensi atau harga bawang merah antarwilayah di Indonesia pada tahun 2019 divergen. Berdasarkan uji Sargan, variabel instrumen valid tidak ditolak, karena nilai $p$ - 
Tabel 3: Hasil Estimasi Konvergensi Harga Pangan Tahun 2019

\begin{tabular}{|c|c|c|c|c|}
\hline Komoditi & Parameters & Koefisien & Standard Error & P-value \\
\hline \multirow[t]{5}{*}{ Bawang Merah } & $P_{i t-1}$ & 1,275 & 0,030 & 0,000 \\
\hline & Implied $\lambda$ & $-0,243$ & & \\
\hline & $\mathrm{AB}_{m 1}$ & $-4,651$ & & 0,000 \\
\hline & $\mathrm{AB}_{m 2}$ & 1,308 & & 0,190 \\
\hline & Sargan Test & 32,884 & & 1,000 \\
\hline \multirow[t]{5}{*}{ Cabe Merah } & $P_{i t-1}$ & 0,990 & 0,028 & 0,000 \\
\hline & Implied $\lambda$ & 0,009 & & \\
\hline & $\mathrm{AB}_{m 1}$ & $-4,886$ & & 0,000 \\
\hline & $\mathrm{AB}_{m 2}$ & $-0,599$ & & 0,548 \\
\hline & Sargan Test & 33,591 & & 1,000 \\
\hline \multirow[t]{5}{*}{ Bawang Putih } & $P_{i t-1}$ & 0,872 & 0,005 & 0,000 \\
\hline & Implied $\lambda$ & 0,136 & & \\
\hline & $\mathrm{AB}_{m 1}$ & $-3,492$ & & 0,000 \\
\hline & $\mathrm{AB}_{m 2}$ & 1,563 & & 0,117 \\
\hline & Sargan Test & 33,902 & & 1,000 \\
\hline \multirow[t]{5}{*}{ Cabe Rawit } & $P_{i t-1}$ & 0,955 & 0,016 & 0,000 \\
\hline & Implied $\lambda$ & 0,045 & & \\
\hline & $\mathrm{AB}_{m 1}$ & $-4,747$ & & 0,000 \\
\hline & $\mathrm{AB}_{m 2}$ & 1,041 & & 0,297 \\
\hline & Sargan Test & 33,934 & & 1,000 \\
\hline
\end{tabular}

Sumber: Hasil perhitungan penulis

value sebesar 1,000 lebih dari taraf nyata 5 persen. Kemudian dalam proses uji konsistensi modelnya, dilakukan dengan melihat tingkat signifikansi pada AB $m 1$ yang signifikan pada taraf nyata 5 persen dan $\mathrm{AB}{ }_{m 2}$ yang tidak signifikan pada taraf nyata 5 persen, yang berarti tidak ada korelasi serial pada model atau dengan kata lain modelnya konsisten.

Konvergensi terjadi pada komoditas cabe merah dengan koefisien $P_{i t-1}$ sebesar 0,990 dan signifikan pada taraf nyata 5 persen. Kecepatan konvergensi sebesar 0,9 persen. Model dinyatakan valid dengan $p$-value uji Sargan sebesar 1.000. Model juga konsisten atau tidak terdapat korelasi serial pada model dengan $\mathrm{AB}_{m 1}$ signifikan pada taraf 5 persen dan $\mathrm{AB}_{m 2}$ tidak signifikan pada taraf 5 persen. Seperti halnya cabe merah, komoditas bawang putih mengalami konvergensi dengan koefisien $P_{i t-1}$ sebesar 0,872 dan kecepatan konvergensi cukup tinggi sebesar 13,6 persen. Nilai p-value pada uji Sargan sebesar 1,000 menyatakan bahwa variabel instrumen valid. Pengujian konsistensi model menunjukan signifikansi $\mathrm{AB}_{m 1}$ pada taraf 5 persen, dan $\mathrm{AB}_{m 2}$ tidak signifikan pada taraf 5 persen sehingga pada model tidak terjadi korelasi serial atau model konsisten.

Pada cabe rawit, koefisien $P_{i t-1}$ sebesar 0,955 dan signifikan pada taraf nyata 5 persen. Artinya harga cabe rawit mengalami proses konvergensi dengan kecepatan sebesar 4,5 persen. Berdasarkan uji Sargan, variabel instrumen valid tidak ditolak, karena nilai $p$-value sebesar 1.000 lebih dari taraf nyata 5 persen. Pengujian konsistensi model dilakukan dengan melihat tingkat signifikansi AB $m 1$ yang signifikan pada taraf nyata 5 persen dan $\mathrm{AB}_{m 2}$ yang tidak signifikan pada taraf nyata 5 persen sehingga menunjukkan bahwa tidak ada korelasi 
serial pada model atau dengan kata lain modelnya konsisten. Tiga dari empat komoditas hortikultura mengalami konvergensi di Indonesia pada tahun 2019. Hasil estimasi konvergensi harga pangan tahun 2020 ditunjukkan oleh Tabel 4.

Tabel 4: Hasil Estimasi Konvergensi Harga Pangan Tahun 2020

\begin{tabular}{|c|c|c|c|c|}
\hline Komoditi & Parameters & Koefisien & Standard Error & $P$-value \\
\hline \multirow[t]{5}{*}{ Bawang Merah } & & 0,958 & 0,007 & 0,000 \\
\hline & Implied $\lambda$ & 0,042 & & \\
\hline & $\mathrm{AB}_{m 1}$ & $-3,983$ & & 0,000 \\
\hline & $\mathrm{AB}_{m 2}$ & $-0,896$ & & 0,370 \\
\hline & Sargan Test & 33,470 & & 1,000 \\
\hline \multirow[t]{5}{*}{ Cabe Merah } & & 0,947 & 0,010 & 0,000 \\
\hline & Implied $\lambda$ & 0,053 & & \\
\hline & $\mathrm{AB}_{m 1}$ & $-5,087$ & & 0 \\
\hline & $\mathrm{AB}_{m 2}$ & $-1,633$ & & 0,102 \\
\hline & Sargan Test & 33,3401 & & 1,000 \\
\hline \multirow[t]{5}{*}{ Bawang Putih } & & 1,996 & 0,019 & 0,000 \\
\hline & Implied $\lambda$ & $-0,691$ & & \\
\hline & $\mathrm{AB}_{m 1}$ & $-4,359$ & & 0,000 \\
\hline & $\mathrm{AB}_{m 2}$ & $-0,3854$ & & 0,699 \\
\hline & Sargan Test & 33,683 & & 1,000 \\
\hline \multirow[t]{5}{*}{ Cabe Rawit } & & 1,0009 & 0,022 & 0,000 \\
\hline & Implied $\lambda$ & $-0,0009$ & & \\
\hline & $\mathrm{AB}_{m 1}$ & $-4,516$ & & 0,000 \\
\hline & $\mathrm{AB}_{m 2}$ & $-0,050$ & & 0,959 \\
\hline & Sargan Test & 32,969 & & 1,000 \\
\hline
\end{tabular}

Pada komoditi bawang merah terjadi proses konvergensi yang terlihat dari nilai koefisien $P_{i t-1}$ sebesar 0,958 dan menghasilkan tingkat konvergensi 4,2 persen. Uji Sargan menunjukkan bahwa variabel instrumen valid tidak ditolak, dengan $p$-value 1,000. Pengujian konsistensi model dilakukan dengan melihat hasil tingkat signifikansi $\mathrm{AB}_{m 1}$ yang signifikan pada taraf nyata 5 persen dan $\mathrm{AB}_{m 2}$ yang tidak signifikan pada tingkat level 5 persen, sehingga menunjukkan bahwa tidak ada korelasi serial pada model atau dengan kata lain modelnya konsisten.

Konvergensi terjadi pada komoditas cabe merah dengan koefisien $P_{i t-1}, 0,947$ dan kecepatan konvergensi sebesar 5,3 persen. Model dinyatakan valid dengan p-value uji Sargan sebesar 1.000. Model juga konsisten atau tidak terdapat korelasi serial pada model dengan $\mathrm{AB}_{m 1}$ signifikan pada taraf nyata 5 persen dan $\mathrm{AB}{ }_{m 2}$ tidak signifikan pada taraf nyata 5 persen.

Komoditas bawang putih dan cabe rawit tidak mengalami konvergensi karena koefisien $P_{i t-1}$ lebih besar dari satu yaitu 1,996 dan 1,0009 secara berurutan. Nilai p-value untuk kedua model pada uji Sargan sebesar 1,000 menyatakan bahwa variabel instrumen valid. Pengujian konsistensi kedua model menunjukan signifikansi $\mathrm{AB}_{m 1}$ pada taraf nyata 5 persen, dan $\mathrm{AB}_{m 2}$ tidak signifikan pada taraf 5 persen sehingga pada model tidak terjadi korelasi serial atau model konsisten.

Berdasarkan Tabel 3 dan 4, terdapat perubahan konvergensi harga pangan 
sebelum dan saat pandemi COVID-19. Pada komoditas bawang merah, pada saat pandemi COVID-19 atau pada tahun 2020 terjadi proses konvergensi dengan kecepatan konvergensi 4,2 persen. Keadaan ini berbeda dibandingkan periode sebelumnya, di mana harga bawang merah antarwilayah di Indonesia divergen. Kemudian pada komoditas cabe merah, nilai koefisien konvergensi berkurang dari 0,990 menjadi 0,958 dan kecepatan konvergensi bertambah dari 0,9 persen menjadi 5,3 persen. Dua komoditas tersebut mengalami kondisi yang lebih baik pada saat pandemi dibandingkan sebelum pandemi COVID-19.

Sementara itu, konvergensi harga bawang putih dan cabe rawit mengalami perubahan sebaliknya. Proses konvergensi yang terjadi pada masa sebelum pandemi COVID-19, tidak terjadi pada masa selama pandemi COVID-19. Harga bawang putih dan cabe rawit pada tahun 2020 antarwilayah di Indonesia dalam kondisi divergen. Hal ini akibat terjadi fluktuasi harga cabe rawit dan bawang putih pada tahun 2020. Harga cabe rawit naik cukup tinggi pada awal tahun 2020 namun anjlok pada pertengahan tahun sehingga terjadi perbedaan harga tertinggi dan terendah yang cukup tinggi. Kondisi tersebut dipengaruhi terhambatnya distribusi karena adanya pembatasan dalam upaya pengendalian penularan COVID-19. Produksi cabe tidak bisa terserap pasar dengan maksimal akibat menurunnya daya beli masyarakat hingga 50 persen (Julitasari \& Suwarta, 2020). Puncaknya, bulan Mei-Juni 2020 yang merupakan puncak panen cabe rawit dari hasil tanam pada Februari-Maret 2020, harga anjlok akibat kelebihan pasokan (Julitasari \& Suwarta, 2020).

Komoditas bawang putih juga mengalami dampak serius akibat COVID-19. Dari sisi impor pangan, Indonesia memiliki ketergantungan terhadap impor bawang putih dari China dan hanya dapat mengimpor bawang putih tersebut sebesar 23.000 ton pada Februari 2020. Angka ini menunjukkan penurunan yang drastis jika dibandingkan dengan impor tahun 2019 yang sebesar 583.000 ton (Budiyanti, 2020). Sebagaimana diketahui, China merupakan negara pertama yang mengalami pandemi COVID-19 sehingga pasokan bawang putih akan terhambat. Akibatnya, bawang putih mengalami kekurangan pasokan sehingga terjadi kenaikan harga yang cukup tinggi pada Februari-Maret 2020 (Budiyanti, 2020). Kementerian Pertanian terus mengupayakan alternatif negara lainnya yang dapat memasok bawang putih dan juga mendorong produksi bawang putih dalam negeri. Bawang putih dan cabe rawit nampaknya harus menjadi fokus utama pemerintah dalam menjaga kestabilan harga pangan sehingga inflasi negara dapat dijaga pada kondisi yang stabil.

\section{Kesimpulan}

Variabilitas harga antarwaktu pada sebelum dan saat pandemi COVID-19 untuk sembilan komoditas menunjukkan perubahan variabilitas yang berbeda. Komoditas beras, daging sapi, cabe merah, mengalami penurunan nilai variabilitas, artinya perbedaan harga tidak terlalu signifikan. Kondisi yang sama juga dialami harga daging ayam dan telur ayam. Sementara itu, gula pasir, bawang merah, 
bawang putih, dan cabe rawit mengalami peningkatan variabilitas harga. Komoditas hortikultura sebagian besar mengalami peningkatan fluktuasi harga akibat pandemi COVID-19. Pada variabilitas harga antarwilayah di Indonesia sebelum dan selama pandemi COVID-19 menunjukkan perubahan variabilitas harga yang cenderung meningkat. Mayoritas variabilitas harga pangan mengalami peningkatan. Hanya variabilitas harga telur ayam yang turun. Artinya perbedaan harga pangan antarwilayah di Indonesia meningkat akibat pandemi COVID-19. Secara keseluruhan, variabilitas harga antarwaktu dan antarwilayah masih dapat dikatakan stabil dan wajar karena nilai perubahan CV di bawah 0,1.

Terdapat perubahan konvergensi harga pangan sebelum dan saat pandemi COVID-19. Harga bawang merah mengalami konvergensi pada tahun 2020, di mana pada tahun sebelumnya tidak terjadi konvergensi atau divergen. Sementara itu, cabe merah mengalami percepatan konvergensi dari periode sebelumnya. Harga bawang putih dan cabe rawit mengalami perubahan sebaliknya. Proses konvergensi yang terjadi pada masa sebelum pandemi COVID-19, tidak terjadi pada masa selama pandemi COVID-19. Harga bawang putih dan cabe rawit pada tahun 2020 antarwilayah di Indonesia dalam kondisi divergen. Hal ini akibat peningkatan fluktuasi harga cabe rawit dan bawang putih pada tahun 2020. Harga cabe rawit anjlok akibat kelebihan pasokan. dan harga bawang putih meningkat signifikan karena kelangkaan akibat impor bawang putih dari China yang berkurang.

Harga komoditas hortikultura yang sangat berfluktuasi selama pandemi COVID-19 karenakan ketidakpastian pasokan dan daya beli masyarakat yang masih lemah. Implementasi dari intervensi pemerintah terkait harga dan pasokan komoditas hortikultura sangat diperlukan disamping penyaluran bantuan sosial. Selain pengelolaan pasokan melalui penataan produksi antarwaktu, efisiensi distribusi antarwilayah menjadi keharusan. Upaya seperti sistem kontrak dengan pasar; sistem resi gudang dan penguatan Badan Usaha Milik Daerah untuk manajemen pasokan pangan semakin krusial. Dengan adanya sistem kontrak, maka ada kejelasan off taker. Untuk kelancaran distribusi dapat diupayakan meskipun ada pembatasan mobilitas karena pembeli sudah jelas berdasarkan kontrak.

\section{Daftar Pustaka}

[1] Badan Ketahanan Pangan Kementerian Pertanian. (2019). Buletin pasokan dan harga pangan. Kementerian Pertanian. Diakses 11 Maret 2021 dari http:/ /bkp.pertanian.go. id/detail-kategori/Buletin.

[2] Badan Pusat Statistik. (2020). Perkembangan indeks harga konsumen/inflasi. Diaskes 2 April 2021 dari https:/ / www.bps.go.id/subject/3/inflasi.html\#subjekViewTab3.

[3] Bank Indonesia. (2020). Tinjauan kebijakan moneter Desember 2020. Diakses 10 Februari 2021 dari https://www.bi.go.id/id/publikasi/laporan/Pages/ Tinjauan-Kebijakan-Moneter-Desember-2020.aspx.

[4] Barro, R. J., Sala-i-Martin, X., Blanchard, O. J., \& Hall, R. E. (1991). Convergence 
across states and regions. Brookings Papers on Economic Activity, 1991(1), 107-182. doi: https://doi.org/10.2307/2534639.

[5] Budiyanti, E. (2020). Dampak virus corona terhadap sektor perdagangan dan pariwisata Indonesia. Info Singkat, 12(4), 19-24. Diakses 23 Desember 2020 dari https://berkas.dpr.go.id/puslit/files/info_singkat/Info\% 20Singkat-XII-4-II-P3DI-Februari-2020-219.pdf.

[6] FAO. (2010). Agriculture and consumer protection. "Dimensions of need - staple foods: What do people eat?". Food and Agriculture Organization. Diakses 15 Februari 2021 dari http://www.fao.org/3/u8480e/u8480e07.htm.

[7] FAO. (2020). Addressing the impacts of COVID-19 in food crises - April-December 2020: FAO's component of the global COVID-19 humanitarian response plan. Food and Agriculture Organization. Diakses 10 Maret 2021 dari http:/ /www.fao.org/documents/ card/en/c/ca8497en/.

[8] Firdaus, M., \& Gunawan, I. (2012). Integration among regional vegetable markets in Indonesia. Journal of International Society for Southeast Asian Agricultural Sciences (ISSAAS), 18(2), 96-106.

[9] Gilbert, C. L., \& Morgan, C. W. (2010). Food price volatility. Philosophical Transactions of the Royal Society B: Biological Sciences, 365(1554), 3023-3034. doi: https://doi.org/10.1098/rstb.2010.0139.

[10] Julitasari, E. N., \& Suwarta, S. (2020). Analisis nilai tambah produk cabe akibat over supply di masa pandemi COVID-19 (Studi di Kecamatan Karangploso Kabupaten Malang). In Conference on Innovation and Application of Science and Technology (CIASTECH 2020), Universitas Widyagama Malang, 02 Desember 2020, pp. 285-292.

[11] Kariyasa, I. K., \& Sinaga, B. M. (2016). Faktor-faktor yang mempengaruhi perilaku pasar jagung di Indonesia. Jurnal Agro Ekonomi, 22(2), 167-194. doi: http://dx.doi.org/10.21082/jae.v22n2.2004.167-194.

[12] Kementerian Perdagangan. (2015). Rencana strategis 2015-2019. Diakses Oktober 2020 dari https://www.kemendag.go.id/id/about-us/strategic-planning/ rencana-strategis-2015-2019.

[13] Magfiroh, I. S., Zainuddin, A., Setyawati, I. K., \& Rahman, R. Y. (2017). Respon harga produsen terhadap perubahan harga konsumen bawang merah di Indonesia. JSEP (Journal of Social and Agricultural Economics), 10(3), 7-15. doi: https://doi.org/10.19184/jsep.v10i3.6481.

[14] Meyer, J., \& von Cramon-Taubadel, S. (2004). Asymmetric price transmission: a survey. Journal of Agricultural Economics, 55(3), 581-611. doi: https://doi.org/10.1111/j.1477-9552.2004.tb00116.x.

[15] Miller, D. J., \& Hayenga, M. L. (2001). Price cycles and asymmetric price transmission in the US pork market. American Journal of Agricultural Economics, 83(3), 551-562. doi: https://doi.org/10.1111/0002-9092.00177.

[16] PIHPS. (2021). Informasi harga pangan antar daerah. Pusat Informasi Harga Pangan Strategis Nasional. Diakses 15 Maret 2021 dari https:/ /hargapangan.id/.

[17] Prastowo, N. J., Yanuarti, T., \& Depari, Y. (2008). Pengaruh distribusi dalam pembentukan harga komoditas dan implikasinya terhadap inflasi. Working paper Bank Indonesia WP/07/2008.

[18] Ramadhani, D. A., \& Sumanjaya, R. (2014). Analisis faktor-faktor yang mempengaruhi ketersediaan kedelai di Indonesia. Jurnal Ekonomi dan Keuangan, 2(3), 131-145.

[19] Sari, D. L. (2010). Analisis spread harga gabah dan beras serta integrasi pasar dan komoditas (Tesis, IPB University). 
[20] Serra, T., \& Gil, J. M. (2013). Price volatility in food markets: can stock building mitigate price fluctuations?. European Review of Agricultural Economics, 40(3), 507-528. doi: https://doi.org/10.1093/erae/jbs041. 